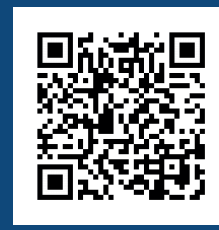

Keywords:

Dendrometric characteristics

Reforestation

Forest soils

Species effects on soils

Received 18/10/2018

Accepted 28/I2/20I8

+Correspondence: dps@pq.uenf.br
Deborah Guerra Barroso', Marilia Grasiela Oliveira da Silva Souza', Taiane Pires de Freitas de Oliveira', David Pessanha Siqueira' ${ }^{1+}$

\section{GROWTH OF ATLANTIC FOREST TREES AND THEIR INFLUENCE ON TOPSOIL FERTILITY IN THE SOUTHEASTERN BRAZIL}

BARROSO, D. G.; SOUZA, M. G.O.S.; OLIVEIRA, T. P. F.; SIQUEIRA, D. P. Growth of Atlantic Forest trees and their influence on topsoil fertility in the southeastern Brazil. CERNE, v. 24, n. 4, p. 352-359, 2018.

\section{HIGHLIGHTS}

All evaluated tree species showed growth increases up to $2 \mathrm{I}$ years.

The evaluated trees have potential for recovery degraded areas.

The edaphic system was able to become self-sustainable under all tree stands.

The evaluated trees changed the topsoil fertility differentially.

\section{ABSTRACT}

The aim of our study was to evaluate the dendrometric characteristics of Atlantic Forest trees of 21 years of deployment in the mountain region of Rio de Janeiro, Brazil and their influence on topsoil fertility. We evaluated the survival rates, total heights, and diameters at $1.30 \mathrm{~m}$ of all trees in the stand. The characterized soil chemical attributes were $\mathrm{pH}$, $\mathrm{P}, \mathrm{K}, \mathrm{Ca}, \mathrm{Mg}, \mathrm{Al}$, and organic matter at 0-0.I $\mathrm{m}$ depth. The averages were compared by Student's test $(p<0.05)$. While Myroxylon peruiferum and Amburana cearensis had lower survival rates than the other species, Plathymenia reticulata had a larger diameter. All tree species showed diameter growth, though it was larger for Dalbergia nigra, Plathymenia reticulata, Schizolobium parahyba, Esenbeckia leiocarpa, and Lecythis Pisonis. All stands showed medium organic matter content, from 3.3 to $4.1 \%$, and low P. The soils under the Dalbergia nigra and Plathymenia reticulata stands are the most acidic and with low $\mathrm{Ca}$, $\mathrm{Mg}$, and $\mathrm{K}$ levels. Our study demonstrated differences in growth patterns and that the species influenced the soil chemical characteristics differently. 


\section{INTRODUCTION}

Brazil is a country that stands out in the forestry sector due to its climatic and soil conditions, the extensive areas available for planting, and its advanced technical achievement, which has rendered it the status of the world's most productive country in terms of timber volume per unit area (lbá, 2017). However, forest exploitation has been restricted to a few species, especially exotic and widely studied ones. In 2016, the total area of trees planted in Brazil was 7.84 million ha, of which 5.7 million were comprised of eucalyptus, I.6 million of pine, and only 0.59 million ha with other species (lbá, 20I7).

To meet the demands of the timber sector without intervening in natural forests, it is fundamental to increase the efficiency and effectiveness of production, exploitation, conversion of raw materials, and, above all, the development of planted areas. The diversification of species and the increase in supply of reforestation wood is a market demand. Studies of timber and non-timber forest species potential production allow the expansion and diversification of products and stimulate the conservation of genetic materials eliminated by logging deforestation.

However, the experience with Brazilian native species is limited, with little knowledge about their potential for commercial exploitation. Thus, the percentage of native forest species as a part of the planted forest statistics is low, as is the case of Hevea brasiliensis and Schizolobium amazonicum (lbá, 2017), even with the wide diversity found in the country.

There are large numbers of degraded areas with productive potential, given appropriate management techniques. The use of these areas could contribute to an increase in the supply of wood and non-timber products, reducing pressure on native forests and the need to import products from other locations.

During their development, forest species can alter soil chemical attributes such as $\mathrm{pH}$ and nutrient content. The literature contains results confirming that tree species have different effects on litter (production and quality) as well as the physical, chemical, and biological properties of topsoil (Firn et al., 2007; Medina-Villar et al., 2015; Kooch et al., 2016; Russell et al., 2018)Nutrient absorption in the deeper layers returns to the soil surface (through litterfall) can help explain the changes in topsoil fertility between forest species (Márquez et al., 1993).

The aim of the present study was to evaluate the dendrometric characteristics of twelve Atlantic Forest trees 21 years after planting and verify the influence of these species on soil chemical attributes in order to infer the potential for the recovery of degraded areas and commercial plantations.

\section{MATERIAL AND METHODS}

\section{Description of study site}

The study was carried out in homogeneous plantations of twelve Atlantic Forest tree species, established in 1992 in the José Zago State Forest, located in the mountain region of Rio de Janeiro, Brazil, within the municipal limits of Trajano de Moraes (Figure I).

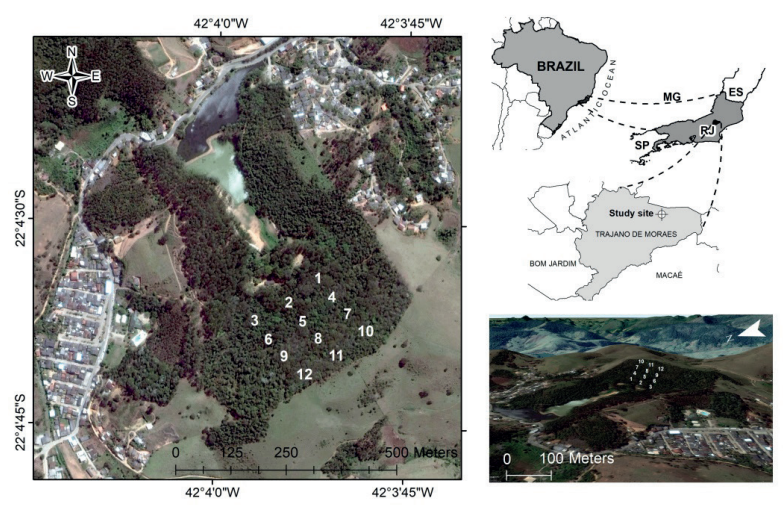

FIGURE I Study area site locations in Trajano de Moraes, southeastern Brazil. I- Preticulata; 2- L. pisonis; 3- D. nigra; 4- H. courbaril; 5- C.tomentosum; 6- S. parahyba; 7- E.leiocarpa; 8- M.peruiferum; 9- C.trichotoma; 10H.heptaphyllus; II- H.vellosoi; I2- A.cearensis).

The species are from the following families: Fabaceae (Hymenaea courbaril Linneaeus, Dalbergia nigra Vellozo Allemão ex Benth, Centrolobium tomentosum Guillem ex Benth, Plathymenia reticulata Benth, Schizolobium parahyba Vellozo S. F. Blake, Esenbeckia leiocarpa Engl, Myroxylon peruiferum Linneaeus f); Bignoneaceae (Handroanthus heptaphyllus Vellozo, Handroanthus vellosoi Tol. Mattos); Lecitidaceae (Lecythis pisonis Cambessédes); Boraginaceae (Cordia trichotoma Vellozo); and Rutaceae (Amburama cearenses Freire Allemão). The climate in the region is mild, with average temperatures between 18 and $24^{\circ} \mathrm{C}$, annual precipitation between I,000 and I,200 mm, and an altitude of $660 \mathrm{~m}$.

In 201I (19 years after the implantation), soil physical analyses (particle density, particle size analysis, and total porosity) were performed in each plantation and in an adjacent area with Brachiaria sp. (Embrapa, 2017). The soil is a Typic Haplohumults, with low activity clay, in wavy relief, ranging from clay loam to clay loam sandy.

The seedlings were produced from seeds collected in the region that contained no markings or 
descriptions of the matrices collected. Planting took place on a $15^{\circ}$ mean slope in an area previously used as pasture (Imperata brasiliensis and Melinis minutiflora) that had experienced erosion. The area preparation was in minimum cultivation, with manual weeding, $0.40 \times 0.40 \mathrm{x}$ $0.40 \mathrm{~m}$ hole construction, and the use of bovine manure ( IO L) and 10-28-06 NPK fertilizer ( I00g).

A total of 49 seedlings per tree species were planted in single plots and spaced at $3 \times 3 \mathrm{~m}$, resulting in 0.53 ha for all evaluated plantations. During the first year after planting, ants were controlled with baits. Several coleopteran attacks occurred, though no control measures were taken, a fact that may have impaired the survival and initial growth of some species. The survival percentage evaluation was carried out in the field 17 years after planting (November 2009).

\section{Dendrometric evaluations}

The diameter at breast height $(\mathrm{DBH})$ of all trees was evaluated in all the stands at 17, 19, and 21 years of age, while heights were assessed at 17 and 21 years of age, from September to November. The girth at breast height (GBH) was determined with a tape measure and the diameter estimated by the equations, for single trunks [I]; for multiple trunks [2], Where: $d_{1}^{n}=$ diameter of each trunk.

$$
\begin{aligned}
& D B H=\frac{G B H}{\pi} \\
& D B H=\left(d_{1}^{2}+d_{2}{ }^{2}+d_{3}^{2}+\ldots+d_{n}^{2}\right)^{1 / 2}
\end{aligned}
$$

The total height was estimated by the superposition of equal angles (Scolforo and Figueiredo Filho, 1998), with the aid of a rod of a known height $(2 \mathrm{~m})$.

From the biometric measurements in the different years, the average annual increases in height and diameter of the different species were calculated as a function of time between measurements.

The quality of the trunks was evaluated in November 2009 ( 17 years after planting in the field). For trunk quality, each tree received a classification from I to 4, whereby 4 referred to a straight trunk, 3 a tortuous trunk, 2 a forked trunk, and I a faulty trunk. The faulty trunk classification was assigned when physical injury or defects were present. The bifurcated trees received grade 2 , regardless of whether the trunks were straight or tortuous.

\section{Soil sampling and analysis}

In all plots, four simple soil samples (at a $0-0.1$ $\mathrm{m}$ depth) were collected in February and March of 201 I around each tree at approximately $20 \mathrm{~cm}$ from the trunk, resulting in a composed sample per tree of each plot (total of 547). For soil sampling litter was first removed from the ground. In the adjacent pasture area (Brachiaria sp.) 64 points were sampled, evenly distributed throughout the area (an $8 \times 8 \mathrm{~m}$ plot), at the same depth. This area has been unmanaged similar in time since planting as that of the tree planting area. The relief was waved, with approximately $30 \%$. Soil under pasture was used as a reference for comparison with the forest species plantations.

All the samples were air dried and taken to the laboratory (Analysis Center of the Dr. Leonel Miranda campus of the Federal Rural University of Rio de Janeiro - UFRRJ). Once in the laboratory, $\mathrm{pH}$ in water, $\mathrm{P}$ and $\mathrm{K}$ contents (extracted with Mehlich solution), $\mathrm{Ca}, \mathrm{Mg}$, and $\mathrm{Al}$ (extracted by I $\mathrm{mol} \cdot \mathrm{L}^{-1} \mathrm{KCl}$ ), total $\mathrm{N}$ (by Kjeldahl method), and the organic carbon (by oxidation with $\mathrm{K}_{2} \mathrm{Cl}_{2} \mathrm{O}_{7}$ ) were determined. The organic matter was determined by the multiplication of the carbon contents by 1.724 , considering that carbon contributes $58 \%$ of the average composition of humus (Embrapa, 2017).

\section{Data analyses}

The biometric and soil data were assessed by random sampling and the means (averages of all surviving plants), considering that has no statistical design and no fill requirements for parametrical analysis, submitted to descriptive analysis and compared by Confidence Interval $(p<0.05)$ by student's t test. The lack of overlap on Confidence Interval in table and graphics $(p<0.05)$ allows, with high statistical support, differ means. Kruskal Wallis test $(p<0.05)$ was used to compare trunk quality data among species (R Core Team, 2017).

Though our study area does not have a statistical design, there is no information about other plantations with these Atlantic forest tree species at this age, which highlights these findings.

\section{RESULTS}

\section{Survival and dendrometric evaluations}

Eight species had over $80 \%$ survival (Table I), whereas no cultural management measures were performed after planting, with the exception of ants control.

The tree species $P$. reticulata and $S$. parahyba had higher diameters at $1.30 \mathrm{~m}$, with 24.0 and 22.3 $\mathrm{cm}$, respectively. The other species presented similar values, except for $M$. peruiferum and $A$. cearensis, which possessed lower diameters (Figure $2 b$ ).

All species had annual diameter increment over four years (2009-20I3). S. parahyba showed the highest increase, with $1.2 \mathrm{~cm}$ year ${ }^{-1}$, followed by $P$. reticulata, with $0.6 \mathrm{~cm} \cdot$ year $^{-1}$ (Figure 3b). The lowest annual diameter increase was in $H$. vellosoi, with $0.1 \mathrm{~cm} \cdot$ year $^{-1}$. 
The total height was highest for P. reticulata (I5.I $\mathrm{m})$, followed by $H$. courbaril $(14.3 \mathrm{~m})$. The tree species $H$. heptaphyllus, $H$. velosoi, E. leiocarpa, M. peruiferum, and $A$. cearensis presented lower growth than other species. Although the second highest total height was observed in $\mathrm{H}$. courbaril, its annual increment in diameter was low $(0.27 \mathrm{~cm})$, with the better trunk quality (Table I).

TABLE I Survival (evaluated at 17 years after planting in the field) and trunk quality (classifications) of Atlantic Forest tree species, southeastern Brazil.

\begin{tabular}{cccc}
\hline Species & $\begin{array}{c}\text { Survival } \\
(\%)\end{array}$ & Trunk quality* \\
& 89.80 & 3.64 & $\mathrm{a}$ \\
Hymanea courbaril Linneaeus & 95.92 & 3.29 & $\mathrm{ab}$ \\
Cordia trichotoma Vellozo & 85.71 & 3.05 & $\mathrm{abc}$ \\
Handroanthus heptaphyllus Vellozo & 93.88 & 2.82 & $\mathrm{abcd}$ \\
Esenbeckia leiocarpa Engl. & 81.63 & 2.76 & $\mathrm{bcd}$ \\
Schizolobium parahyba Vellozo S. F. Blake & 77.55 & 2.73 & $\mathrm{bcd}$ \\
Handroanthus vellosoi Tol. Mattos & 100.00 & 2.65 & $\mathrm{bcd}$ \\
Plathymenia reticulata Benth & 93.88 & 2.62 & $\mathrm{bcd}$ \\
Centrolobium tomentosum Guillem ex Benth & 73.47 & 2.59 & $\mathrm{~cd}$ \\
Lecythis pisonis Cambessédes & 83.67 & 2.08 & $\mathrm{de}$ \\
Dalbergia nigra Vellozo Allemão ex Benth & 63.27 & 2.50 & $\mathrm{de}$ \\
Myroxylon peruiferum Linneaeus & 46.94 & 2.00 & $\mathrm{e}$ \\
Amburana cearenses Freire Allemão & &
\end{tabular}

*Different letters in each column indicates significant differences $(p<0.05$ by Kruskal Wallis test).
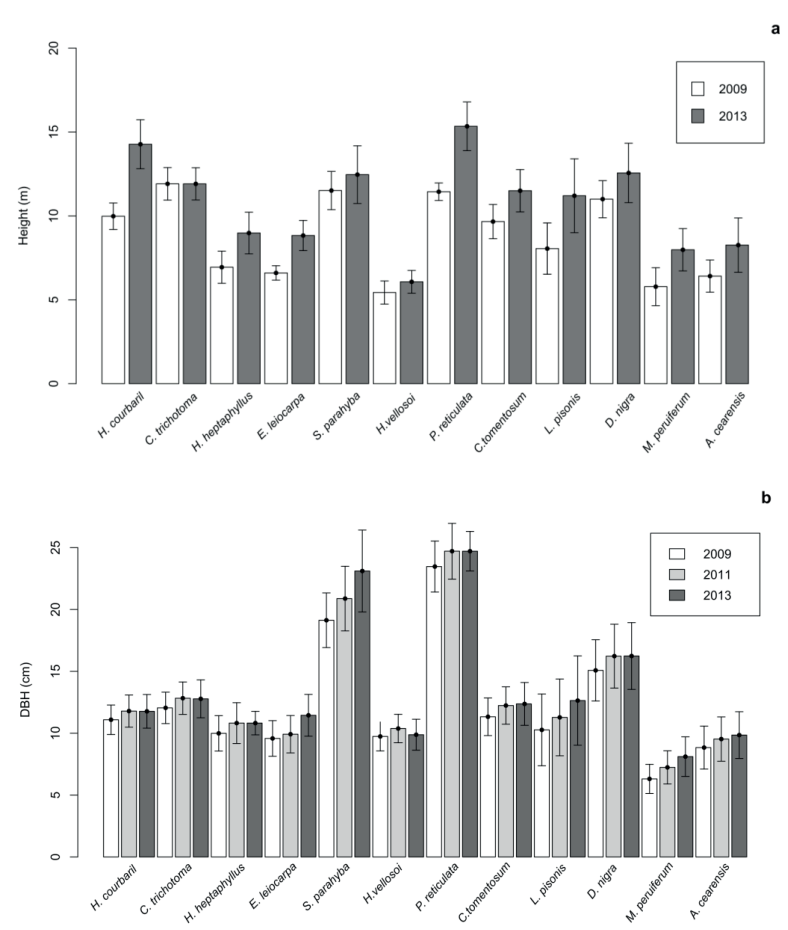

FIGURE 2 Total height (a) and diameter at $1.30 \mathrm{~m}$ (b; DBH) of Atlantic Forest tree species planted in 1992 in southeastern Brazil.
E. leiocarpa showed several thin forks, reducing timber production. Although $P$. reticulata forked in almost $100 \%$ of trees, the trunks were at most three with none of them like in the $E$. leiocarpa stand. P. reticulata presented mostly rectilinear trunks, free of defects, suggesting $P$. reticulata's potential for timber production.

Topsoil fertility

The soil under Brachiaria sp. showed higher Al content than most forest species, lower only than $P$. reticulata and $D$. nigra soils (Table 2 ). The $\mathrm{pH}$ values of all plantations varied from 4 to 6 and the soil under P. reticulata and $D$. nigra was 4.3 and 4.9 , respectively, the lowest values. Despite the low values in these forest stands, both species had a good development, showing adaptation.

The $\mathrm{Ca}$ content in soil under Brachiaria sp. did not differ from the soil under $L$. pisonis, $C$. tomentosum, or $H$. courbaril stands. The soils under the $C$. trichotoma, $H$. heptaphyllus, E. leiocarpa, A. cearensis, $H$. vellosoi, and
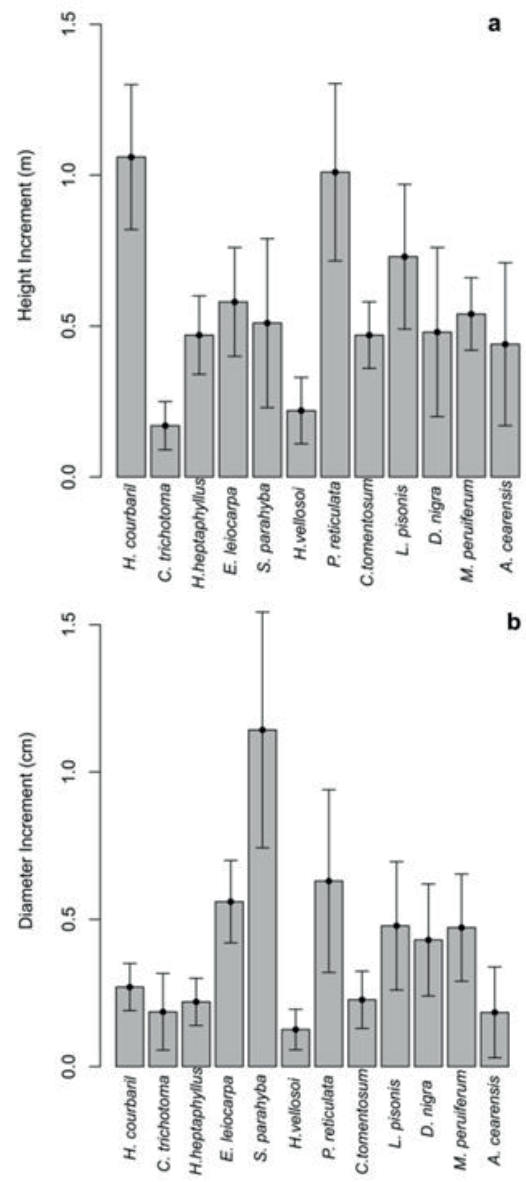

FIGURE 3 Height (a) and diametric increments (b) over four years $(2009-2013)$ of Atlantic Forest tree species planted in 1992 in southeastern Brazil. 
M. peruiferum stands showed higher $\mathrm{Ca}$ content and lower Al content when compared to Brachiaria sp. soil.

While the $\mathrm{K}$ and $\mathrm{Ca}$ contents were higher in the soils under Brachiaria sp. than in the soils under the Fabaceae stands, they did not differ from those of A. cearensis or M. peruiferum. All plots showed organic matter between $3.3 \%$ and $4.1 \%$.

\section{DISCUSSION}

Survival and dendrometric evaluations

M. peruiferum had a lower than expected survival rate, likely due to planting in full sun. As this species needs some shade for healthy development (Sebbenn et al., 1998), the lack of shading may have reduced the survival rate of the species in our study. The intercropping of $M$. peruiferum with species of different successional groups would be a measure that could help provide the required shade.

A. cearensis, however, appears suitable for recovery efforts in degraded areas (Almeida et al., 20l4). The low survival rates in the present study were probably related to the lack of cultural management measures after planting. Moreover, there were reports of pest attacks in this stand, which may have contributed to reductions in the survival rate. A. cearensis is tolerant of different lighting conditions, growing well under conditions ranging from full sun to $50 \%$ shading (Ramos et al., 2004).

The pioneer tree species $S$. parahyba is not merely of economic interest, but due to its potential as an alternative species for the recovery of degraded areas.
A comparison of a young S. parahyba plantation with an area under a 25-year period of natural regeneration showed higher litter and fine root production in the young S. parahyba plantation (Silva et al., 20I I). Although in Silva et al. (20II) work S. parahyba promoted the reestablishment of nutrients and organic matter cycling, this species was only associated with organic matter and the $P$ level increases in the present study.

During the first years of development tree species tend to grow exponentially, as in the case of an $H$. courbaril stand, which showed $6.0 \mathrm{~m}$ of total height, $8.6 \mathrm{~cm}$ of diameter at $1.30 \mathrm{~m}$, and an annual diameter increment of $1.2 \mathrm{~cm}$ at seven years after planting (Tonini et al., 2005). An II year old $H$. courbaril stand in a soil with low $\mathrm{pH}$ and cation exchange capacity (CEC) showed $16.5 \mathrm{~m}$ of total height and $16.5 \mathrm{~cm}$ of diameter at $1.30 \mathrm{~m}$ with the highest survival rate $(94.4 \%)$ when compared to other species (Souza et al., 2008). These findings show the potential for $H$. courbaril plantations slated for timber production. However, in the edaphoclimatic conditions of our study area, the species showed lower diameter growth and increase. $H$. courbaril wood is already used in contruction and for furniture and frame production and flour from its fruits can be used as food (CalderónPeralta et al., 2017).All tree species showed growth increases up to 21 years. When the decomposition rate of the leaves on the ground is low, there may be losses in stand success, as observed in eucalyptus and native forest stands in western, Santa Catarina State (Inkotte et al., 20I5). The litterfall contribution by all tree species as

TABLE 2 Chemical topsoil properties (mean \pm confidence interval*) under Atlantic Forest tree stands at 19 years old in southeastern Brazil.

\begin{tabular}{|c|c|c|c|c|c|c|c|}
\hline \multirow{2}{*}{ Species } & $\mathrm{pH}$ & Al & $P$ & $\mathrm{~K}$ & $\mathrm{Ca}$ & $\mathrm{Mg}$ & OM \\
\hline & & $\mathrm{cmol}_{\mathrm{c}} \cdot \mathrm{dm}^{-3}$ & $\mathrm{mg} \cdot \mathrm{dm}^{-3}$ & $\mathrm{mg} \cdot \mathrm{dm}^{-3}$ & $\mathrm{cmol}_{\mathrm{c}} \cdot \mathrm{dm}^{-3}$ & $\mathrm{cmol}_{\mathrm{c}} \cdot \mathrm{dm}^{-3}$ & $\%(m / v)$ \\
\hline H. courbaril & $5.0( \pm 0.11)$ & $0.71( \pm 0.15)$ & $2.59( \pm 0.20)$ & $59.11( \pm 8.4)$ & $1.84( \pm 0.28)$ & $0.84( \pm 0.09)$ & $3.3( \pm 0.13)$ \\
\hline C. trichotoma & $5.6( \pm 0.08)$ & $0.11( \pm 0.05)$ & $2.94( \pm 0.26)$ & $126.43( \pm|| .2)$ & $3.48( \pm 0.35)$ & $1.85( \pm 0.12)$ & $3.9( \pm 0.13)$ \\
\hline H. heptaphyllus & $5.6( \pm 0.05)$ & $0.17( \pm 0.06)$ & $3.29( \pm 0.56)$ & I $97.83( \pm$ I8.5) & $4.86( \pm 0.49)$ & $2.17( \pm 0.17)$ & $4.1( \pm 0.18)$ \\
\hline E. leiocarpa & $5.6( \pm 0.05)$ & $0.15( \pm 0.05)$ & $4.61( \pm 0.83)$ & $183.83( \pm 16.1)$ & $4.00( \pm 0.47)$ & $1.44( \pm 0.11)$ & $3.8( \pm 0.11)$ \\
\hline S. parahyba & $5.2( \pm 0.07)$ & $0.45( \pm 0.07)$ & $3.53( \pm 0.19)$ & $73.25( \pm 4.0)$ & $2.13( \pm 0.20)$ & I.II $( \pm 0.07)$ & $4.1( \pm 0.10)$ \\
\hline H. vellosoi & $5.5( \pm 0.04)$ & $0.19( \pm 0.05)$ & $3.58( \pm 2.02)$ & $131.97( \pm 16.5)$ & $4.30( \pm 0.37)$ & $2.46( \pm 0.14)$ & $3.7( \pm 0.13)$ \\
\hline P. reticulata & $4.3( \pm 0.05)$ & $1.48( \pm 0.12)$ & $3.53( \pm 0.26)$ & $56.55( \pm 3.7)$ & $0.68( \pm 0.17)$ & $0.55( \pm 0.10)$ & $4.1( \pm 0.15)$ \\
\hline C. tomentosum & $5.3( \pm 0.05)$ & $0.4 \mathrm{I}( \pm 0.07)$ & $2.74( \pm 0.20)$ & $67.59( \pm 5.6)$ & $1.56( \pm 0.22)$ & $1.28( \pm 0.11)$ & $3.5( \pm 0.11)$ \\
\hline L. pisonis & $5.3( \pm 0.08)$ & $0.27( \pm 0.08)$ & $2.61( \pm 0.26)$ & $55.81( \pm 4.7)$ & $1.91( \pm 0.25)$ & $1.21( \pm 0.14)$ & $3.3( \pm 0.16)$ \\
\hline D. nigra & $4.9( \pm 0.07)$ & $1.15( \pm 0.13)$ & $2.66( \pm 0.24)$ & $54.00( \pm 3.8)$ & $0.99( \pm 0.20)$ & $0.77( \pm 0.15)$ & $3.8( \pm 0.13)$ \\
\hline M. peruiferum & $5.6( \pm 0.05)$ & $0.17( \pm 0.06)$ & $2.68( \pm 0.22)$ & $145.23( \pm 19.5)$ & $3.12( \pm 0.37)$ & $1.75( \pm 0.14)$ & $3.5( \pm 0.15)$ \\
\hline A. cearenses & $5.5( \pm 0.08)$ & $0.17( \pm 0.09)$ & $2.48( \pm 0.22)$ & $94.13( \pm 17.8)$ & $3.96( \pm 0.64)$ & $1.94( \pm 0.15)$ & $3.9( \pm 0.19)$ \\
\hline Brachiaria sp. & $5.3( \pm 0.04)$ & $0.92( \pm 0.12)$ & $4.78( \pm 0.76)$ & $114.92( \pm 19.2)$ & $1.60( \pm 0.18)$ & $1.02( \pm 0.10)$ & $3.7( \pm 0.12)$ \\
\hline
\end{tabular}

OM = Organic matter; $*$ Confidence Interval $(p<0.05)$. 
well the decomposition rate were probably effective at maintaining species development by providing nutrients through nutrient cycling, though further studies on litter deposition and decomposition need to be done to confirm this hypothesis. External nutrient supply was only carried out during seedling planting.

Despite its good development, Preticulata received a low trunk quality score (2.50) due to the presence of forks. However, its trunks possessed a low crooked degree and had the highest diameters at $1.30 \mathrm{~m}$.

\section{Topsoil fertility}

Although a specific trend for topsoil fertility was not observed for Fabaceae tree species, they were associated with diazotrophic bacteria that fixes $N$ to soil. The Plathymenia species have nodulation capacity (Furtini Neto et al., 2000; Vítková et al., 2015), which may explain the soil acidity found under them in the present study. In addition, $C$. tomentosum also shows root system nodulation and nitrate absorption capacity (Aidar and Joly, 2003); however, in this study assessments of the soil under this species did not show the same trend as with the $P$. reticulata soil, with low $\mathrm{Al}, \mathrm{P}$, and organic matter for C. tomentosum plantation.

$\mathrm{Ca}$ is easily leached by rainwater on slopes, and the highest $\mathrm{Ca}$ content will therefore probably be found in basin areas. In our study, the soils under $P$. reticulata, $L$. pisonis, and $D$. nigra, which help form the basin of the study area (Figure I), showed lower Ca content in relation to the other stands, and $\mathrm{Ca}$ availability was therefore certainly affected by soil $\mathrm{pH}$ variations. All stands showed medium $\mathrm{Ca}$ soil content (Furtini Neto et al., 2000) from I.2I to $2.40 \mathrm{cmolc} \cdot \mathrm{dm}^{3}$, with the exception of the soils under $P$. reticulata and $D$. nigra that exhibited lower levels.

$H$. heptaphyllus, $H$. vellosoi, $A$. cearensis, and $E$. leiocarpa were the plots with highest soil $\mathrm{Ca}$ content. Some of these species presented trunk debarking and bark usually contains higher Ca content (Witschoreck and Schumacher, 20I3). P. reticulata has high bark production with low debarking that falls to the ground (visual perception), keeping the $\mathrm{Ca}$ in bark and consequently a lower cycling and soil return. The bark also contributes with $\mathrm{K}, \mathrm{Mg}$, and $\mathrm{P}$ and the nutrient content can be higher than in the timber, and may vary from 2.2 times for $P$ to 34.8 times for $\mathrm{Ca}$ (Andrade et al., 20I I).

All plots presented $>50 \mathrm{mg} \mathrm{dm}^{-3}$ of $\mathrm{K}$, considered an average to high range (Furtini Neto et al., 2000), particularly the soils under $H$. heptaphyllus, E. leiocarpa, $H$. vellosoi, C. trichotoma, and $M$. peruiferum ( $>120 \mathrm{mg} \cdot \mathrm{dm}^{3}$ ), the very soils that showed high levels of $\mathrm{Mg}$ and $\mathrm{Ca}$ and low levels of $\mathrm{Al}$. These species likely accumulate little $\mathrm{K}$ and instead exude it into the soil system. The soil under Brachiaria sp. also showed high $\mathrm{K}$ content, with no differences among the soil under the forest species. $\mathrm{K}, \mathrm{Ca}$, and $\mathrm{Mg}$ are available at low levels in very weathered tropical soils.

There was little variation in $\mathrm{P}$ contents among the stands; all were lower than $6 \mathrm{mg} \cdot \mathrm{dm}^{-3}$, a level considered very low $\left(\leq 6.6 \mathrm{mg} \cdot \mathrm{dm}^{-3}\right)$ for silvicultural plantations (Furtini Neto et al., 2000). The soil under Brachiaria sp. also showed low $\mathrm{P}$, with no differences in relation to $H$. vellosoi and $E$. leiocarpa soils, but higher than the soils under the other stands. The $\mathrm{P}$ content in the pasture can be explained by the fact that root systems have higher volumes in upper soil layers. The continuous root growth and decomposition process contribute to organic matter decomposition, increasing $\mathrm{P}$ availability and absorption (Brunner et al., 2013) as well as other nutrients, such as $\mathrm{K}, \mathrm{Ca}$, and $\mathrm{Mg}$.

Acidic soils fix $P$, resulting in low $P$ availability (Chase and Singh, 2014). While the soil under $P$ reticulata showed a $P$ content similar to the other stands, this soil was the most acidic, suggesting that high acidity may not have impaired $\mathrm{P}$ availability or Preticulata's growth. Low $\mathrm{pH}$ inhibits the mineralization of organic soil matter and therefore soil nutrient levels are not enhanced. Clay particles can lose their CEC when soil acidity increases (Nsabimana et al., 2008) due to nutrient stock decreases or leaching, reducing nutrient availability, as observed in the soil under $P$. reticulata and D.nigra with low $\mathrm{K}, \mathrm{Ca}$, and $\mathrm{Mg}$. This fact can also explain the higher $\mathrm{K}, \mathrm{Ca}$, and $\mathrm{Mg}$ and lower $\mathrm{Al}$ levels under the $H$. heptaphyllus, $E$. leiocarpa, $H$. vellosoi, $C$. trichotoma, and $M$. peruiferum stands.

Higher $\mathrm{pH}, \mathrm{Ca}, \mathrm{K}$, and $\mathrm{P}$ content levels have been found in forest soils when compared to those of pasture (Loss et al., 2009). This trend is due to the nutrient cycling (litter and roots) present in forest areas, an essential process for the development and maintenance of vegetation. In our study, $\mathrm{K}$ and $\mathrm{Ca}$ levels in most of the soils under tree species were higher than in those under pasture. However, the $\mathrm{P}$ content results did not corroborate the findings of the authors cited above, despite small variations among the areas. In the Atlantic Forest rapid mineralization of organic matter can occur due to high temperature, humidity, and rainfall, all contributing factors for nutrient cycling.

Soil fertility can be altered by plant characteristics, age, root systems, species interaction, litter quantity and quality, its decomposition, $\mathrm{N}$ fixation, and $\mathrm{Al}$ accumulation (Russell et al. 2018). Areas with R. pseudoacacia have 
tended to have the greatest organic soil matter, $\mathrm{N}$, and $\mathrm{P}$ than those of the soil under A. altissima (Medina-Villar et al., 2015). Alnus subcordata and Populus deltoids in Northern Iran also improved the soil fertility (greater $\mathrm{P}, \mathrm{K}, \mathrm{Ca}$, and $\mathrm{Mg}$ availability) and biological activities attributed to rapid nutrient cycling in young secondary forests (Kooch et al., 2016).

In a different way, afforestation with Cupressus. lusitanica was not able to restore organic soil carbon and total nitrogen to their original levels. Rapid organic soil matter mineralization can be reflected in lower organic soil carbon content (Chase and Singh, 20l4; Wainkwa Chia et al., 2017). In our study area, further studies on litterfall (quantity and quality) and nutrient cycling (decomposition rates) need to be carried out to better understand species effects on soil.

Compared with Brachiaria sp., the soil under H.courbaril and L. Pisonis stands had lower organic matter. The organic matter of all forest stands can be considered medium (Schumacher et al., 2004), from 3.3 to $4.1 \%$. The Rio de Janeiro mountain region has a rainfall trend characterized by rainy periods followed by drought, a microclimate that fosters organic matter decomposition. Trees quickly cover the soil with litterfall, reducing the effects of weathering and erosion while enhancing topsoil fertility (Stark et al., 2015) and increasing soil microorganism levels (Garcia-Franco et al., 20I5). In addition, the organic matter can increase soil aggregation, CEC, water infiltration rates, and soil moisture maintenance (Silva and Mendonça, 2007).

\section{CONCLUSIONS}

These Atlantic forest trees have potential for the recovery of degraded areas.

The trees changed the topsoil fertility differentially, with higher acidity and lower $\mathrm{Ca}, \mathrm{Mg}$, and $\mathrm{K}$ soil contents under $P$. reticulata and $D$. nigra stands. Despite the differences in soil chemical attributes, the edaphic system was able to become self-sustainable over the medium to long terms under all tree stands, enhancing productivity and soil conservation.

Based on the growth results, the species $P$. reticulata and S. parahyba have potential for silvicultural plantations and timber production, even in degraded areas.

\section{ACKNOWLEDGEMENTS}

We are grateful to the José Zago State Forest administrators, Rio de Janeiro State Research Foundation [Grant number: E26/I I I.612/20 I0], and National Council for Scientific and Technological Development [Grant numbers: 303585/20 I I-0; 48647/20 I I-0; I4 I 5 I3/20 I7-

9] for their assistance in this study.

\section{REFERENCES}

AIDAR, M.P.M.; JOLY, G.A. Dynamics of litter production and decomposition of araribá (Centrolobium tomentosum Guill. ex Benth. - Fabaceae) in a riparian forest, Jacaré-Pepira river, São Paulo. Revista Brasileira de Botânica, v.26, n. I, p. 193-202, 2003.

ALMEIDA, J.P.N.; PINHEIRO, C.L.; LESSA, B.F.T.; GOMES, F.M.; MEDEIROS FILHO, S. Estresse hídrico e massa de sementes na germinação e crescimento de plântulas de Amburana cearensis (Allemão) A. C. Smith. Revista de Ciências Agronômicas, v.45, n.4, p.777-787, 2014.

ANDRADE, M.C.N.; MINHONI, M.T.A.; SANSÍGOLO, C.A.; ZIED, D.C.; SALES-CAMPOS, C. Comparative study of the nutritional constituition of wood and bark of species and clones of Eucalyptus aiming the cultivation of Shiitaki in longs. Revista Árvore, v.35, p.183-192, 2011.

BRUNNER, I.; BAKKER, M.R.; BJORK, R.G.; HIRANO, Y.; LUKAC, M.; ARANDA, X.; BORJA, I.; ELDJUSET, T.D.; HELMISAARI, H.S.; JOURDAN, C.; KONÔPKA, B.; LÓPEZ, B.C.; PÉREZ, M.; PERSSON, H.; OSTONEN, I. Fine-root turnover rates of European forests revisited: an analysis of data from sequential coring and ingrowth cores. Plant Soil, v. I, p.362-357, 2013.

CALDERÓN-PERALTA, C.V.; JIMÉNEZ-HERNÁNDEZ, J.; MALDONADO, A.Y.; FLORES-CASAMAYOR, V.; ARÁMBULA-VILLA, G.; SALAZAR, R. Influence of Hymenea courbaril gum as a new addictive on nixtamalized flour properties and quality of tortilla. Journal of Food Process Engeneering, v. 40, p.el2525, 2017.

CHASE, P.; SINGH, O.P. Soil nutrients and fertility in three traditional land use systems of Khonoma, Nagaland, India. Resources and Environment, v.4, n. 4, p.18I-189, 2014.

EMBRAPA, 2017. Manual de métodos de análises de solo. Centro Nacional de Pesquisas de Solos. Brasília, 2017, 575p.

FIRN, J.; ERSKINE, P.D.; LAMB, D. Woody species diversity influences productivity and soil nutrient availability in tropical plantations. Oecologia, v. I54, n.3, p.52I-533, 2007.

FURTINI NETO, A.E.; SIQUEIRA, J.O.; CURI, N.; MOREIRA, F.M.S. Fertilização em reflorestamento com espécies nativas. In: GONÇALVES, J.L.M.; BENEDETTI, V. Nutrição e Fertilização Florestal. Piracicaba-IPEF, 2000. p. 35I-383.

GARCIA-FRANCO, N.; MARTÍNEZ-MENA, M.; GOBERNA, M.; ALBALADEJO, J. Changes in soil aggregation and microbial community structure control carbon sequestration after afforestation of semiarid shrublands. Soil Biology and Biochemistry, v.87, p. II0-I2I, 2015.

Industria Brasileira de Árvores - IBÁ (2017) http://iba.org/ images/shared/Biblioteca/IBA_RelatorioAnual2017.pdf Acessed in 22 February 2018. 
INKOTTE, J.; MAFRA, A.L.; RIOS, P.A.; BARETTA, D.; VIEIRA, H.C. Litter fall deposition in Eucalyptus plantations and native forests in the highland and west regions of Santa Catarina, Southern Brazil. Scientia Forestalis, v.43, n.I06, p.26I-270, 2015.

KOOCH, Y.; ROSTAYEE, F.; HOSSEINI, S.M. Effect of tree species on topsoil and nitrogen cycling in natural forest and tree plantations of northern Iran. Catena, v. I44, p.65-73, 2016.

LOSS, A.; PEREIRA, M.G.; BERNINI, T.A.; MORAES, A.G.L.; ZATORRE, N.P.; WALDT, P.G.S. Fertility, Carbon and Nitrogen from Soil Humic Substances in Succession ForestPasture in Acre. Revista Brasileira de Agroecologia, v.4, p.I298-I30I, 2009.

MÁRQUEZ, O.; HERNÁNDEZ, R.; TORRES, A.; FRANCO, W. Cambios en las propriedades físico-químicas de los suelos em una cronosecuencia de Tectona grandis. Turrialba, v. I, p. 37-4I, 1993.

MEDINA-VILLAR, S.; CASTRO-DIÉZ, P.; ALONSO, A.; CABRARIVAS, I.; PARKER, I.M.; PÉREZ-CORONA, E. Do the invasive trees, Ailanthus altíssima and Robinia pseudoacacia, alter litterfall dynamics and soil properties of riparian ecossystems in Central Spain? Plant Soil v.396, p. 31 I:324, 2015.

NSABIMANA, D.; KLEMEDTSON, L.; KAPLIN, B.A.; WALLIN, G. Soil carbon and nutrient accumulation under forest plantations in southern Rwanda. African Journal Environmental Science Tecnology, v. 2, p. I42-I49, 2008.

RAMOS, K.M.O.; FELFILI, J.M.; FAGG, C.W.; SOUSA-SILVA, J.C.; FRANCO, A.C. Initial growth and biomass allocation of Amburana cearensis (Allemao) A.C. Smith, under different levels of shade. Acta Botânica Brasilica, v. 18, n.2, p.35I358, 2004.

RUSSELL, A.E.; KIVLIN, S.N.; HAWKES, C. Tropical tree species effects on soil $\mathrm{pH}$ and biotic factors and the consequences for macroaggregate dynamics. Forests v.9, n.4, p. I-14, 2018

R CORE TEAM: A language and environment for statistical computing. $\mathbf{R}$ foundation for Statistical Computing, Vienna, Austria, 2017.

SCHUMACHER, M.V.; BRUN, E.J.; KONING, F.G.; KLEINPAUL, J.J.; KLEINPAUL, I.S. Análise de nutrientes para sustentabilidade. Revista da Madeira, 2004. http:// www.remade.com.br/br/revistadamadeira materia. php?num =60I . Acessed 24 October 2017.
SCOLFORO, J.R.S; FIGUEIREDO FILHO, A. Biometria florestal: medição e volumetria de árvores florestais. Federal University of Lavras, Lavras, MG, 1998. 310p.

SEBBENN, A.M.; SIQUEIRA, A.C.M.F;; KAGEYAMA, P.Y.; MACHADO, J.A.R. Genetic Parameters in the Conservation of Cabreuva - Myroxylon peruiferum L.F. Allemão. Scientia Forestalis, v.53, p. 31-38, 1998.

SILVA, I.R.; MENDONÇA, E.S. Matéria Orgânica do Solo. In: NOVAIS, R.F; ALVAREZ, V. H.; BARROS, N.F; FONTES, R.L.; CANTARUTTI, R.B.; NEVES, J.C.L. Fertilidade do solo. Sociedade Brasileira de Ciências do Solo, 2007. p 276-357.

SILVA, A.K.L.; VASCONCELOS, S.S.; CARVALHO, C.J.R. Litter dynamics and fine root production in Schizolobium parahyba var. amazonicum plantations and regrowth forest in Eastern Amazon. Plant Soil, v. 347, p. 377-386, 20 I I.

SOUZA, C.R.; LIMA, R.M.B.; AZEVEDO, C.P.; ROSSI, L.M.B. Efficiency of forest species for multiple use in Amazonia Scientia Forestalis, v.36, n.77, p.7-I4, 2008.

STARK, H.; NOTHDURFT, A.; BLOCK, J.; BAUHUS, J. Forest restoration with Betula ssp. and Populus ssp. nurse crops increases productivity and soil fertility. Forest Ecology and Management, v. 399, p.5770, 2015

TONINI, H.; ARCO-VERDE, M.F.; SÁ, S.P.P. Dendrometry of native species in homogeneous stands in the Roraima State - andiroba (Carapa guianensis Aubl), castanha-dobrasil (Bertholletia excelsa Bonpl), ipê-roxo (Tabebuia avellanedae Lorentz ex Griseb) and jatobá (Hymenaea courbaril L.) Acta Amazonica, v.35, p. 353-362, 2005.

VÍTKOVÁ, M.; TONIKA, J.; MULLEROVÁ, J. Black locust successful invader of a wide range of soil conditions. Science of the Total Environment, v.505, p.3I5-328, 2015.

WAINKWA CHIA, R.; KIM, D.G.; YIMER, F. Can afforestation with Cupressus lusitanica restore soil $\mathrm{C}$ and $\mathrm{N}$ stocks depleted by crop cultivation to levels observed under native systems? Agriculture, Ecossystems and Environment, v. 242, p.65-75, 2017.

WITSHHOREC, R.; SCHUMACHER, M.V. Nutrients content and allocation in Platanus $\mathrm{x}$ acerifolia (Aiton) Willd. plantations in Dom Feliciano, Rio Grande do Sul State. Ciência Florestal, v. 4, p.667678, 2013. 